\title{
Pengaruh Promosi dan Inovasi Produk terhadap Keputusan Pembelian Mobil Toyota Avanza (Studi Kasus di Auto 2000 Veteran Palembang)
}

\author{
M. Fikri Hidayatullah ${ }^{1)}$, Muhammad Wadud ${ }^{2)}$, Roswaty ${ }^{3)}$ \\ 1), 2), 3) Universitas Indo Global Mandiri, Palembang, Indonesia \\ Email: fikri070298@gmail.com ${ }^{1)}$,wadud@uigm.ac.id ${ }^{2)}$,roswaty@uigm.ac.id ${ }^{3)}$
}

\begin{abstract}
Abstrak
Penelitian ini bertujuan untuk menginvestigasi pengaruh promosi dan inovasi produk terhadap keputusan pembelian mobil Toyota Avanza pada Auto 2000 Veteran Palembang. Data dikumpulkan melalui observasi dan kuesioner pada 38 responden. Studi ini menggunakan metode analisis regresi linier berganda. Hasil investigasi membuktikan bahwa secara parsial, baik promosi maupun inovasi produk berpengaruh signifikan terhadap keputusan pembelian. Secara simultan, promosi dan inovasi produk berpengaruh signifikan terhadap keputusan pembelian. Berdasarkan hasil analisis ini, produsen mobil Toyota Avanza sebaiknya menguatkan promosi dan meningkatkan kemampuan berinovasi untuk menambah penjualan.
\end{abstract}

Kata Kunci: promosi, inovasi produk, keputusan pembelian, perilaku konsumen, pemasaran

\begin{abstract}
This study aims to investigate the effect of promotion and product innovation on purchasing decisions for a Toyota Avanza at Auto 2000 Veteran Palembang. Data were collected through observation and questionnaires to 38 respondents. This study uses multiple linear regression analysis. The results of the investigation prove that partially, both promotion and product innovation have a significant effect on purchasing decisions. Simultaneously, promotion and product innovation have a significant effect on purchasing decisions. Based on the results of this analysis, the Toyota Avanza car manufacturer should strengthen promotions and increase the ability to innovate to increase sales.
\end{abstract}

Keywords: promotion, product innovation, purchasing decisions, consumer behavior, marketing

\section{Pendahuluan}

Setiap aktivitas manusia dari satu tempat ke tempat lain membutuhkan alat transportasi, mulai dari sepeda, motor, mobil dan sampai pesawat udara. Terkait dengan aktivitas di darat yang tidak terlalu jauh, mobil merupakan salah satu pilihan konsumen, termasuk konsumen di Kota Palembang. Banyak produk mobil yang digunakan, merek-merek mobil yang dipasarkan di Kota Palembang dapat dilihat dari berbagai merek yang dipajang oleh tiap-tiap dealer. Perkembangan dunia industri otomotif semakin pesat. Terlihat dari kenaikan jumlah permintaan mobil yang semakin meningkat selama beberapa tahun terakhir. Dealer-dealer mobil yang terdapat di Kota Palembang membuat persaingan industry otomotif menjadi sangat kuat. Kondisi tersebut jika diamati dari dimensi bisnis dan aktivitas pemasaran memiliki pengaruh besar dalam merumuskan kebijakan bisnis industri otomotif di masa datang. Kebijakan strategi pemasaran merupakan alternatif. Strategi pemasaran menurut Kotler and Amstrong (2012) adalah logika pemasaran dimana perusahaan berharap dapat menciptakan nilai bagi customer dan dapat mencapai hubungan yang menguntungkan dengan pelanggan.

Menurut Shinta (2011), Manajemen pemasaran adalah suatu usaha untuk merencanakan, mengimplementasikan (yang terdiri dari kegiatan mengorganisasikan, mengarahkan, 
mengkoordinir) serta mengawasi atau mengendalikan kegiatan pemasaran dalam suatu organisasi agar tercapai tujuan organisasi secara efesien dan efektif. Mobil merek Toyota khususnya selain dipandang sebagai alat transportasi masal juga sebagai mobil pribadi yang dibutuhkan masyarakat Indonesia di Kota Palembang. Motivasi pemilikan dan pembelian mobil merek Toyota didasarkan pada nilai ekonomis dan kebutuhan yang harus ada sebagai alat transportasi untuk bekerja, berekreasi dan sebagainya, bahkan untuk saat ini banyak keluarga yang memiliki mobil lebih dari satu. Faktor yang menentukan keputusan pembelian konsumen, salah satunya yaitu promosi. Menurut Buchari (2016), definisi promosi adalah sejenis komunikasi yang memberi penjelasan yang meyakinkan calon konsumen tentang barang dan jasa. Tujuan promosi ialah memperoleh perhatian, mendidik, mengingatkan, dan meyakinkan calon konsumen.

Faktor lainnya yang mempengaruhi keputusan pembelian adalah inovasi produk. Menurut Dhewanto (2014), inovasi produk merupakan hasil dari pengembangan produk baru oleh suatu perusahaan atau industri baik yang sudah ada maupun belum. Dari produk lama yang telah mencapai titik jenuh dipasaran, diperlukan sebuah inovasi untuk mengganti produk lama tersebut. Penggantian ini dapat berupa produk pengganti yang secara total baru atau dengan perkembangan produk lama yang lebih modern dan up to date, sehingga dapat terus meningkatkan keinginan konsumen dalam keputusan pembelian produk tersebut. Dari fenomena yang terjadi pada Toyota yang mengeluarkan inovasi produk mobil Avanza, dan penjualan yang sangat baik dari Toyota untuk mempromosikan mobil jenis Avanza ini, maka peneliti tertarik untuk melakukan observasi pada AUTO 2000 Veteran Palembang. Dengan penelitian ini dapat melihat pengaruh apa yang menjadi keputusan pembelian masyarakat Indonesia pada mobil Toyota Avanza sehingga banyak menjadi pilihan bagi masyarakat indonesia. Berdasarkan uraian diatas maka peneliti tertarik untuk melakukan penelitian dengan judul "Pengaruh Promosi dan Inovasi ProdukTerhadap Keputusan Pembelian Mobil Toyota Avanza di AUTO 2000 Veteran Palembang".

\section{Tinjauan Pustaka}

Menurut Suprapto et al. (2020:), pemasaran adalah suatu proses sosial dan manajerial yang didalamnya individu dan kelompok mendapatkan apa yang mereka butuhkan dan inginkan dengan menciptakan, menawarkan, dan mempertukarkan produk yang bernilai dengan pihak lain. Tujuan pemasaran menurut Freddy Rangkut (2002) pada umumnya dibuat berdasarkan target penjualan. Tapi dapat juga sebaliknya, tujuan pemasaran dibuat dalam rangka mencapai target penjualan yang telah diterapkan.

Promosi merupakan elemen bauran pemasaran yang berfokus pada upaya menginformasikan, membujuk, dan mengingatkan kembali konsumen akan merek dan produk perusahaan (Tjiptono, 2015; Marnisah, Saputra, \& Azraie, 2016; Susanti, Halin, \& Kurniawan, 2018). Pada era revolusi industri 4.0, promosi sudah serba digital, termasuk di antaranya adalah dengan implementasi media sosial (Wahid \& Wadud, 2020). Menurut Kotler dan Armstrong (2012), bauran promosi terdiri atas lima alat-alat promosi, yaitu:

a. Periklanan, yaitu semua bentuk presentasi dan promosi nonpersonal yang dibayar oleh sponsor untuk mempresentasikan gagasan, barang atau jasa.

b. Promosi penjualan, yaitu insentif-insentif jangka pendek untuk mendorong pembelian atau penjualan suatu produk atau jasa. Bentuk promosi yang digunakan mencakup discounts, coupons, displays, demonstrations, contests, sweepstakes, dan events. 
c. Penjualan perseorangan, yaitu presentasi personal oleh tenaga penjualan dengan tujuan menghasilkan penjualan dan membangun hubungan dengan konsumen. Bentuk promosi yang digunakan mencakup presentations, trade shows, dan incentive programs.

d. Hubungan masyarakat, yaitu membangun hubungan yang baik dengan berbagai publik perusahaan supaya memperoleh publisitas yang menguntungkan, membangun citra perusahaan yang bagus, dan menangani atau meluruskan rumor, cerita, serta eventyang tidakmenguntungkan. Bentuk promosi yang digunakan mencakup press releases, sponsorships, special events, dan web pages.

e. Penjualan langsung, yaitu hubungan langsung dengan sasaran konsumen dengan tujuan untuk memperoleh tanggapan segera dan membina hubungan yang abadi dengan konsumen. Bentuk promosi yang digunakan mencakup catalogs, telephone marketing, kiosks, internet, mobile marketing, dan lainnya.

Manurut Robbins \& Coulter (2016) inovasi sendiri didefinisikan sebagai mengambil ide-ide kreatif dan mengubahnya menjadi produk atau metode kerja yang berguna. Suatu usaha bisnis yang mampu membuat inovasi maka usaha tersebut dapat memimpin dan memperkecil kemungkinan kompetitor untuk melakukan inovasi lebih awal. Menurut Lukas dan Ferrell (2000) menjelaskan adanya beberapa indikator dari inovasi produk, yaitu:

a. Perluasan Produk (line extensions), Perluasan produk merupakan produk yang masih familiar bagi organisasibisnis tetapi baru bagi pasar.

b. Peniruan Produk (me-too products), Peniruan produk merupakan produk yang dianggap baru oleh bisnis tetapifamiliar dengan pasar.

c. Produk Baru (new-to-the-world products), Produk baru merupakan produk yang dianggap baru baik oleh bisnismaupun oleh perusahaan.

Keputusan pembelian adalah kegiatan yang dilakukan oleh penjual dalam menjual barang atau jasa dengan harapan akan memperoleh laba dari adanya transaksi-transaksi tersebut, sang penjual memastikan, mengaktivasi dan memuaskan kebutuhan atau keinginan si pembeli agar dicapai manfaat baik bagi sang penjual maupun bagi sang pembeli yang berkelanjutan dan menguntungkan (Arifai \& Trihandayani, 2018; Irawan, Marnisah, \& Azrai'e, 2018; Batu, Suryani, Septia, \& Sekaryahya, 2020). Menurut Kotler dan Keller (2012) menyatakan terdapat enam indikator keputusan pembelian dilakukan oleh konsumen yaitu:

a. Pemilihan Produk

b. Pemilihan Merek

c. Pemilihan Saluran Pembelian

d. Jumlah Pembelian

e. Waktu Pembelian

Pada setiap penelitian tentunya dibutuhkan sebuah landasan teori, guna untuk memperkuat atau mendukung metode dan analisi yang dilakukan. Berikut ini merupakan referensi penelitian terdahulu yang dapat dilihat:

Penelitian Azmiani Batubara dan Rahmat Hidayat (2016) yang berjudul Pengaruh Penetapan Harga dan Promosi terhadap Tingkat Penjualan Tiket pada PSA Mihin Lanka Airlines. Kesimpulan yang dapat diambil dari hasil penelitian adalah (1) secara simultan penetapan harga 
dan promosi berpengaruh positif dan signifikan terhadap tingkat penjualan tiket pada PSA Mihin Lanka Airlines Medan (2) secara parsial penetapan harga dan promosi berpengaruh terhadap positif dan signifikan terhadap tingkat penjualan tiket pada PSA Mihin Lanka Airlines Medan, variabel yang mendominasi mempengaruhi tingkat penjualan adalah penetapan harga.

Kerangka Pemikiran menggambarkan hubungan dari variabel independen, dalam hal ini adalah Promosi $\left(\mathrm{X}_{1}\right)$, dan Inovasi Produk $\left(\mathrm{X}_{2}\right)$ terhadap variabel dependen yaitu keputusan pembelian (Y) yang dilakukan oleh konsumen.

Gambar 1. Kerangka Pemikiran

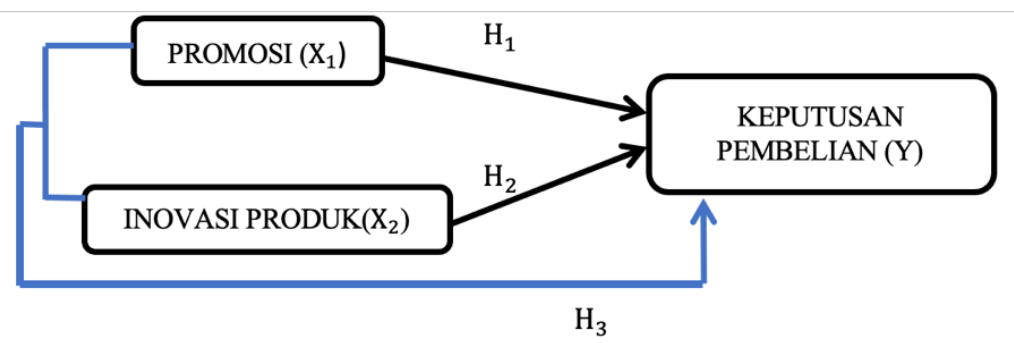

Dari kerangka pemikiran di atas, maka dapat di ketahui, bahwa yang menjadi variabel independen/bebas adalah promosi $\left(\mathrm{X}_{1}\right)$ dan inovasi produk $\left(\mathrm{X}_{2}\right)$, sedangkan yang menjadi variabel dependen/terikat adalah keputusan pembelian (Y).

Adapun hipotesis yang diajukan dalam penelitian ini adalah sebagai berikut:

$\mathrm{H}_{1}$ : Diduga terdapat pengaruh antara promosi $\left(\mathrm{X}_{1}\right)$ secara parsial terhadap keputusan pembelian (Y) mobil Toyota Avanza di AUTO 2000 Veteran Palembang.

$\mathrm{H}_{2}$ :Diduga terdapat pengaruh antara inovasi produk $\left(\mathrm{X}_{2}\right)$ secara parsial terhadap keputusan pembelian (Y) mobil Toyota Avanza di AUTO 2000 Veteran Palembang.

$\mathrm{H}_{3}$ :Diduga terdapat pengaruh antara promosi $\left(\mathrm{X}_{1}\right)$ dan inovasi produk $\left(\mathrm{X}_{2}\right)$ secara simultan terhadap keputusan pembelian (Y) mobil Toyota Avanza di AUTO 2000 Veteran Palembang.

\section{Metodologi}

Penelitian ini akan membahas masalah yang berkaitan dengan pengaruh promosi dan inovasi produk terhadap keputusan pembelian pada mobil Toyota Avanza. Dalam penelitian ini menggunkan jenis dan sumber data kuantitatif yaitu data penjualan pada bulan Januari-Juni 2020 yang digunakan pihak perusahaan dan inovasi produk mobil Avanza pada dealer Toyota Auto2000 Veteran di kota Palembang yang yang dinyatakan dalam bentuk angka. Data ini merupakan hasil dari perhitungan dan pengukuran suatu variabel. Teknik Pengumpulan data yang dilakukan dengan menyebarkan kuesioner kepada responden, dengan cara mendatangi langsung pihak responden yang telah membeli produk mobil Toyota Avanza. Di sini yang sebagai pihak responden dari konsumen langsung yang pernah membeli atau baru membeli. Sampel pada penulisan ini meliputi sebanyak 38orang berdasarkan data yang didapat pada populasi konsumen yang telah membeli produk Toyota Avanza pada Auto2000 Veteran. Teknik analisis data menggunakan SPSS. Dan alternatif jawaban secara likert. 


\section{Hasil dan Pembahasan}

\subsection{Uji Validitas}

Alat ukur yang digunakan dalam pengujian validitas adalah daftar pertanyaan yang telah diisi oleh responden dan akan diuji hasilnya guna menunjukkan valid tidaknya suatu data. Dasar pengambilan keputusannya adalah:

1. Jika $r$ hitung $>$ r table, maka butir atau pernyataan tersebut valid

2. Jika $r$ hitung $<$ r table, maka butir atau pernyataan tersebut tidak valid

Untuk melakukan pengujian validitas instrumen dilakukan dengan menggunakan bantuan (SPSS).

Tabel 1. Hasil uji validitas variabel promosi $\left(\mathrm{X}_{1}\right)$

\begin{tabular}{|l|l|l|l|}
\hline Item & $\mathrm{R}_{\text {Hitung }}$ & $\mathrm{R}_{\text {Tabel }}$ & Keterangan \\
\hline Promosi 1 & 0,794 & 0,320 & Valid \\
\hline Promosi 2 & 0,766 & 0,320 & Valid \\
\hline Promosi 3 & 0,635 & 0,320 & Valid \\
\hline Promosi 4 & 0,820 & 0,320 & Valid \\
\hline Promosi 5 & 0,663 & 0,320 & Valid \\
\hline Promosi 6 & 0,672 & 0,320 & Valid \\
\hline
\end{tabular}

Berdasarkan hasil pada tabel 1 di atas dapat kita lihat semua sudah berada di atas nilai $\mathrm{r}_{\text {tabel }}$ yaitu 0,320 dalam menentukan batas minimal validitas dan juga setiap pertanyaan sudah signifikan (a $>0,05 \%$ ) sehingga dapat disimpulkan semua item pertanyaan valid.

Tabel 2. Hasil uji validitas variabel inovasi $\operatorname{produk}\left(\mathrm{X}_{2}\right)$

\begin{tabular}{|l|l|l|l|}
\hline Item & $\mathrm{R}_{\text {Hitung }}$ & $\mathrm{R}_{\text {Tabel }}$ & Keterangan \\
\hline Inovasi Produk 1 & 0,663 & 0,320 & Valid \\
\hline Inovasi Produk 2 & 0,658 & 0,320 & Valid \\
\hline Inovasi Produk 3 & 0,680 & 0,320 & Valid \\
\hline Inovasi Produk 4 & 0,678 & 0,320 & Valid \\
\hline Inovasi Produk 5 & 0,679 & 0,320 & Valid \\
\hline Inovasi Produk 6 & 0,594 & 0,320 & Valid \\
\hline
\end{tabular}


Berdasarkan hasil spss tabel 2 di atas dapat kita lihat semua sudah berada di atas nilai $\mathrm{r}_{\text {tabel }}$ yaitu 0,320 dalam menentukan batas minimal validitas dan juga setiap pertanyaan sudah signifikan (a $>0,05 \%$ ) sehingga dapat di simpulkan semua item pertanyaan valid.

Berdasarkan hasil tabel 3 di bawah dapat kita lihat semua sudah berada di atas nilai $\mathrm{R}_{\text {Tabel }}$ yaitu 0,320 dalam menentukan batas minimal validitas dan juga setiap pertanyaan sudah signifikan (a $>0,05 \%$ ) sehingga dapat di simpulkan semua item pertanyaan valid.

Tabel 3. Uji validitas keputusan pembelian (Y)

\begin{tabular}{|l|l|l|l|}
\hline Item & $\mathrm{R}_{\text {Hitung }}$ & $\mathrm{R}_{\text {Tabel }}$ & Keterangan \\
\hline Keputusan Pembelian 1 & 0,430 & 0,320 & Valid \\
\hline Keputusan Pembelian 2 & 0,824 & 0,320 & Valid \\
\hline Keputusan pembalian 3 & 0,827 & 0,320 & Valid \\
\hline Keputusan pembalian 4 & 0,680 & 0,320 & Valid \\
\hline Keputusan pembalian 5 & 0,567 & 0,320 & Valid \\
\hline Keputusan pembalian 6 & 0,345 & 0,320 & Valid \\
\hline Keputusan pembalian 7 & 0,433 & 0,320 & Valid \\
\hline
\end{tabular}

\section{Uji Reliabilitas}

Tabel 4. Hasil uji reliabilitas

\begin{tabular}{|l|l|l|l|}
\hline Variabel & $\begin{array}{l}\text { Cronchbach's } \\
\text { Alpha }\end{array}$ & Ketentuan $\mathrm{R}_{\text {tabel }}$ & Hasil \\
\hline Promosi $\left(\mathrm{X}_{1}\right)$ & 0,782 & 0.6 & Reliabel \\
\hline Inovasi Produk $\left(\mathrm{X}_{2}\right)$ & 0,756 & 0.6 & Reliabel \\
\hline Keputusan Pembelian $(\mathrm{Y})$ & 0,742 & 0.6 & Reliabel \\
\hline
\end{tabular}

Hasil uji reliabilitas tersebut menunjukan semua variabel mempunyai koefisien alpha yang cukup besar yaitu diatas 0.6 sehingga dapat dikatakan semua konsep pengukur masing-masing variabel dari kuesioner reliabilitas sehingga untuk selanjutnya item-item pada masing-masing konsep variabel tersebut layak digunakan sebagai alat ukur.

\subsection{Uji Normalitas}

Terdapat dua cara untuk melakukan uji normalitas yaitu dengan metode grafik Histogram dan Normal P-P Plot, dan menggunakan uji Kolmogrov-Smirnov. Dalam penelitian ini hanya menggunakan metode grafik Histogram dan Normal P-P Plot, hasilnya adalah sebagai berikut:

Gambar 2 di bawah menunjukkan bahwa grafik histogram memiliki pola distribusi normal. Sehingga dapat disampaikan residual memenuhi asumsi normalitas. 
Gambar 2. Histogram

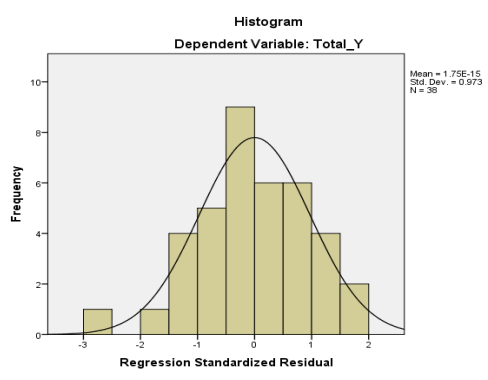

Berdasarkan gambar 3 grafik $P$-P Plot juga menunjukkan bahwa data menyebar di sekitar garis diagonal, sehingga dapat dinyatakan normal.

Gambar 3. Uji P-P Plot

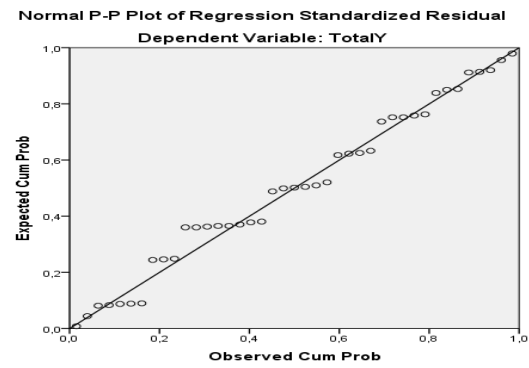

\subsection{Analisis Regresi Linier Berganda}

Penelitian ini menggunakan metode regresi linier berganda untuk melihat bagaimana keadaan (naik turunnya) variabel dependen (kriterium) bila dua atau lebih variabel independen sebagai faktor prediktor dimanipulasi (dinaik turunkan jumlahnya) dengan persamaan sebagai berikut :

Tabel 5. Hasil Uji Linier Berganda

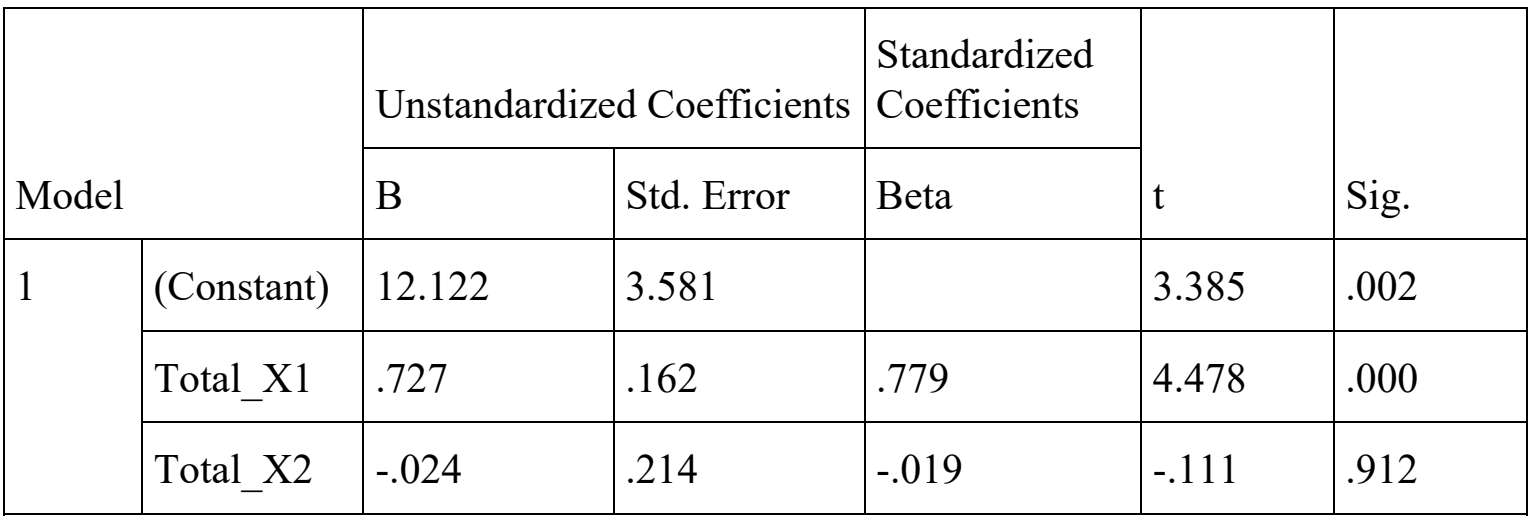

a. Dependent Variable: Total_Y

Bedasarkan tabel 5 diatas, maka nilai konstanta dan koefisien regresi dapat dibentuk menjadi:

$$
\mathrm{Y}=12.122+0.727 \mathrm{X}_{1}-0.024 \mathrm{X}_{2}
$$

Nilai koefisien regresi linier berganda adalah 12.122 sehingga $\mathrm{X}_{1}$ dan $\mathrm{X}_{2}$ tidak mengalami peningkatan atau 0, maka keputusan pembelian adalah sebesar 12.122 satuan. Promosi ditingkatkan sebesar 1 (satu) satuan, maka akan di ikuti dengan keputusan pembelian 
mengalami kenaikan sebesar 0.727 satuan dan bila inovasi produk ditingkatkan 1 (1) satuan maka keputusan pembelian mengalami penurunan sebesar $(-0.024)$.

\subsection{Uji t (Statistik)}

Uji t atau uji parsial digunakan untuk menguji bagaimana pengaruh masing-masing variabel bebasnya (independen) secara sendiri-sendiri terhadap variabel terikatnya (dependen). Tingkat signifikansi yang digunakan adalah $0,05(\alpha=5 \%)$.

Tabel 6. Menguji Singnifikan Variabel Promosi $\left(X_{1}\right)$

\begin{tabular}{|c|c|c|c|c|c|c|}
\hline & & \multicolumn{2}{|c|}{ Unstandardized Coefficients } & \multirow{2}{*}{$\begin{array}{l}\text { Standardized } \\
\text { Coefficients }\end{array}$} & \multirow[b]{2}{*}{$\mathrm{t}$} & \multirow[b]{2}{*}{ Sig. } \\
\hline \multicolumn{2}{|c|}{ Model } & B & Std. Error & & & \\
\hline \multirow[t]{2}{*}{1} & (Constant) & 11.851 & 2.595 & & 4.567 & .000 \\
\hline & Total_X1 & .713 & .100 & .764 & 7.099 & .000 \\
\hline
\end{tabular}

a. Dependent Variable: Total_Y

Bedasarkan data tabel 6 diperoleh $t_{\text {hitung }}$ sebesar 7,099.

Kriteria diterimanya hipotesis:

- Jika t-hitung > t-tabel maka $\mathrm{H}_{\mathrm{o}}$ ditolak dan $\mathrm{H}_{1}$ diterima.

- Jika t-hitung $<$ t-tabel maka $\mathrm{H}_{\mathrm{o}}$ diterima dan $\mathrm{H}_{1}$ ditolak.

- Taraf nyata $<5 \%$ drajat kebebasan $(\mathrm{df})=\mathrm{n}-2=38-2=36$

Dari hasil perhitungan diatas diketahui bahwa nilai t-hitung sebesar 7,099 $>$ t-tabel $(7,099>2,02)$ hal ini berarti $\mathrm{H}_{\mathrm{o}}$ ditolak dan $\mathrm{H}_{1}$ diterima, sehingga dapat disimpulkan bahwa promosi berpengaruh secara singnifikan terhadap keputusan pembelian.

Tabel 7. Menguji Singnifikan Variabel Inovasi Produk $\left(\mathrm{X}_{2}\right)$

\begin{tabular}{|c|c|c|c|c|c|c|}
\hline & & \multicolumn{2}{|c|}{$\begin{array}{l}\text { Unstandardized } \\
\text { Coefficients }\end{array}$} & \multirow{2}{*}{\begin{tabular}{|l|}
$\begin{array}{l}\text { Standardized } \\
\text { Coefficients }\end{array}$ \\
Beta
\end{tabular}} & \multirow[b]{2}{*}{$\mathrm{t}$} & \multirow[b]{2}{*}{ Sig. } \\
\hline \multicolumn{2}{|c|}{ Model } & $B$ & Std. Error & & & \\
\hline \multirow[t]{2}{*}{1} & (Constant) & 10.960 & 4.417 & & 2.481 & .018 \\
\hline & Total_X2 & .723 & .166 & .587 & 4.354 & .000 \\
\hline
\end{tabular}

Bedasarkan data tabel 4.7 diperoleh $t_{\text {hitung }}$ sebesar 4,354.

Kriteria diterimanya hipotesis :

- Jika t-hitung $>$ t-tabel maka $\mathrm{H}_{\mathrm{o}}$ ditolak dan $\mathrm{H}_{1}$ diterima. 
- Jika t-hitung $<$ t-tabel maka $\mathrm{H}_{\mathrm{o}}$ diterima dan $\mathrm{H}_{1}$ ditolak.

- Taraf nyata $<5 \%$ drajat kebebasan $(\mathrm{df})=\mathrm{n}-2=38-2=36$

Dari hasil perhitungan diatas diketahui bahwa nilai t-hitung sebesar 4,354>t-tabel $(4,354>2,02)$ hal ini berarti $\mathrm{H}_{\mathrm{o}}$ ditolak dan $\mathrm{H}_{1}$ diterima, sehingga dapat disimpulkan bahwa inovasi produk berpengaruh secara singnifikan terhadap keputusan pembelian.

\subsection{Uji F (Pengujian Simultan)}

Uji F dimana untuk mengetahui signifikan atau tidak pengaruh variabel bebas terhadap variabel terkait, maka digunakan probability sebesar $5 \%(\alpha=0,05)$. Dan jika probability $\mathrm{F}$ lebih besar dari 0,05 maka model regresi tidak dapat digunakan atau memprediksi variabel dependen dengan kata lain variabel indenpenden secara bersama-sama tidak berpengaruh terhadap variabel dependen.

Ho $: \mathrm{b} 1=\mathrm{b} 2=$ Tidak terdapat pengaruh secara simultan antara promosi dan Inovasi produk terhadap keputusan pembelian mobil Toyota Avanza di AUTO2000 Veteran Palembang

Ho : b1 b2 $\neq 0=$ Terdapat pengaruh secara simultan antara promosi dan Inovasi Produk terhadap keputusan pembelian pada mobil Toyota Avanza di AUTO2000 Veteran Palembang

Dasar pengambilan keputusan Menurut (Sujarweni dan Endrayanto, 2012):

1. Pengambilan keputusan bedasarkan nilai t-hitung:

a. Jika Fhitung $>$ Ftabel, maka Ho ditolak, Ha diterima (berarti ada pengaruh)

b. Jika Fhitung < Ftabel, maka Ho diterima, Ha ditolak (berarti tidak ada pengaruh).

Dengan penentuan Ftabel:

Derajat kepercayaan 5\% dengan uji dua sisi, di mana:

$\mathrm{V} 1=\mathrm{K}=$ Jumlah variabel independen

$$
\mathrm{V} 2=\mathrm{n}-\mathrm{k}-1=38-2-1=35 \quad \text { Ftabel }=(2: 35)
$$

2. Setelah dilakukan pengujian maka diperoleh hasil sebagai berikut:

Tabel 8. Hasil Uji Singnifikan Simultan (Uji Statistik F)

\begin{tabular}{|l|l|l|l|l|l|l|}
\hline \multicolumn{2}{|l|}{ Model } & Sum of Squares & Df & Mean Square & F & Sig. \\
\hline \multirow{3}{*}{1} & Regression & 273.520 & 2 & 136.760 & 24.516 & $.000^{\mathrm{b}}$ \\
\cline { 2 - 8 } & Residual & 195.243 & 35 & 5.578 & & \\
\cline { 2 - 7 } & Total & 468.763 & 37 & & & \\
\hline
\end{tabular}

a. Dependent Variable: Total_Y

b. Predictors: (Constant), Total_X2, Total_X1 
Pada tabel 9 dalam model ANOVA dapat diperoleh nilai Fhitung $(24,516)>$ nilai Ftabel $(3,27)$ dan nilai signifikan $(0,000)<$ tingkat kesalahan $(\alpha=0,05)$ maka Ho ditolak dan Ha diterima, sehingga dapat disimpulkan bahwa promosi dan inovasi produk berpengaruh secara signifikan terhadap keputusan pembelian. Hal ini berarti hipotesis ketiga penelitian ini dapat diterima.

\subsection{Koefisien Korelasi $(R)$}

Koefisien korelasi adalah nilai yang menunjukan kuat atau tidaknya hubungan linier antara dua variabel. Keofisien korelasi biasa dilambangkan dengan huruf $r$ dimana nilai $r$ dapat bervariasi dari 1 - sampai +1 . Nilai $r$ yang mendekati -1 atau +1 menunjukan hubungan yang kuat antara dua variabel nilai $r$ yang mendekati 0 mengidikasikan lemahnya hubungan antara dua variabel tersebut. Dengan hasil pengolahan data SPSS diperoleh dari hasil sebagai berikut:

Tabel 9. Koefisien Korelasi (R)

Model Summary

\begin{tabular}{|l|l|l|l|l|}
\hline Model & R & R Square & Adjusted R Square & Std. Error of the Estimate \\
\hline 1 & $.764^{\mathrm{a}}$ & .583 & .560 & 2.362 \\
\hline
\end{tabular}

a. Predictors: (Constant), Total_X2, Total_X1

Dari tabel diatas diperoleh nilai koefisien korelasi (R) adalah sebesar $\mathbf{0 , 7 6 4}$. Hal ini menunjukan terdapat hubungan yang erat/kuat antara variabel promosi(X1) dan inovasi produk(X2) terhadap keputusan pembelian (Y) sebesar (76,4\%).

\subsection{Koefisien Determinasi $\left(R^{2}\right)$}

Dimana model linier berganda ini, akan dilihat besarnya kontribusi untuk variabel bebas secara bersama-sama terhadap variabel terkait dengan melihat besarnya koefisien determinasi totalnya $\left(\mathrm{R}^{2}\right)$. Jika $\left(\mathrm{R}^{2}\right)$ yang diperoleh mendekati 1 (satu) maka dapat dikatakan semangkin kuat model tersebut menerangkan hubungan variabel bebas terhadap variabel terkait. Untuk mengetahui seberapa besar pengaruh $\mathrm{X}$ terhadap variabel $\mathrm{Y}$ dengan menggunakan koefisien determinasi $\left(\mathrm{R}^{2}\right)$ yang dinyatakan dalam persentase:

Tabel 10. Koefisien Determinasi $\left(\mathrm{R}^{2}\right)$

Model Summary

\begin{tabular}{|l|l|l|l|l|}
\hline Model & $\mathrm{R}$ & R Square & Adjusted R Square & Std. Error of the Estimate \\
\hline 1 & $.764^{\mathrm{a}}$ & .583 & .560 & 2.362 \\
\hline
\end{tabular}

a. Predictors: (Constant), Total_X2, Total_X1

Dari hasil perhitungan diatas maka dapat disimpulkan bahwa ada pengaruh variabel promosi dan inovasi produk terhadap keputusan pembelian sebesar 58,3\%.

\section{Kesimpulan}

Setelah melakukan penelitian dengan berbagai macam pengujian dan analisis data, maka peneliti mencoba memaparkan pembahasan yang menunjukan pengaruh promosi dan inovasi 
produk terhadap keputusan pembelian mobil Avanza di Toyota AUTO2000 Veteran Palembang.

Bedasarkan hasil penelitian dan pembahasan pada bab sebelumnya, maka dapat dibuat kesimpulan sebagai berikut:

a. Hasil penelitian dengan menggunakan Uji t dari variabel promosi diperoleh t-hitung $>$ ttabel $(7,099>2,02)$ dan taraf signifikan $<0,05(0,000<0,05)$. Jadi dapat disimpulkan secara parsial variabel promosi berpengaruh signifikan terhadap keputusan pembelian mobil Toyota Avanza pada AUTO 2000 Veteran Palembang.

b. Hasil penelitian dengan menggunakan Uji t dari variabel inovasi produk diperoleh thitung $>$ t-tabel $(4,354>2,02)$ dan taraf signifikan $<0,05(0,000<0,05)$. Jadi dapat disimpulkan secara parsial variabel inovasi produk berpengaruh signifikan terhadap keputusan pembelian mobil Toyota Avanza pada AUTO 2000 Veteran Palembang.

c. Hasil penelitian dengan menggunakan Uji $\mathrm{F}$ dari variabel promosi dan inovasi produk diperoleh Fhitung $>$ Ftabel $(24,516>3,27)$ dan taraf signifikan $<0,05(0,000<0,05)$. Jadi dapat disimpulkan secara simultan variabel promosi dan inovasi produk berpengaruh secara signifikan pada keputusan pembelian mobil Toyota Avanza pada AUTO 2000 Veteran Palembang.

d. Dari hasil uji Koefisien Korelasi (R) diperoleh nilai sebesar 0,764. Jadi dapat disimpulkan hubungan variable promosi (X1) dan inovasi produk (X2) memiliki hubungan yang kuat terhadap keputusan pembelian (Y) yaitu sebesar 76,4\%.

e. Dari hasil penelitian Koefisien Determinasi $\left(\mathrm{R}^{2}\right)$ diperoleh nilai sebesar 0,583. Hal ini menunjukan besarnya kontribusi variabel promosi (X1) dan inovasi produk (X2) dapat menjelaskan keputusan pembelian (Y) sebesar 58,3\%, sisanya sebesar 41,7\% bisa dijelaskan/dipengaruhi oleh variabel lain yang tidak dimasukan dalam penelitian ini.

\section{Saran}

Berdasarkan kesimpulan di atas, maka penulis akan memberikan saran yang berkaitan dengan penelitian yang telah dilakukan bagi perusahaan, sebagai berikut:

a. Hasil penelitian menunjukkan bahwa indikator dari variabel promosi yang mempunyai pengaruh paling kuat terhadap keputusan pembelian adalah promosi penjualan, maka perusahaan perlu mempertahankandan memperkuat lagi promosi penjualan yang beragam dan sesuai dengan kebutuhan masyarakat.

b. Hasil penelitian menunjukkan bahwa indikator dari variabelinovasi produk yang mempunyai pengaruh lemah dari variabel promosi terhadap keputusan pembelian adalah kesesuaian atau keserasian, maka perusahaan harus lebih menciptakan inovasi produk yang sesuai dengan nilai pasar yang semakin berkembang, kualitas produk, dan mengembangkan inovasi produk yang serasi.

c. Perusahaan harus memperhatikan promosi dan inovasi produk karena mempengaruhi keputusan pembelian terhadap mobil Toyota Avanza, demi untuk meningkatkan penjualan di AUTO 2000 Veteran.

Sementara bagi peneliti selanjutnya, saran yang kami berikan adalah sebagai berikut: 
a. Bagi penelitian selanjutnya dapat menambahkan variabel lain sebagai variabel independen, guna mengetahui variabel-variabel yang dapat memperkuat atau memperlemah variabel dependen.

b. Diharapkan hasil penelitian ini dapat dipakai sebagai bahan referensi bagi penelitian selanjutnya, untuk mengembangkan penelitian inipeneliti selanjutnya juga dapat menambahkan variabel lainnya seperti keputusan pembelian untuk menjadi bahan tambahan penelitian untuk mendapatkan hasil yang lebih baik.

\section{Referensi}

Arifai, A. A., \& Trihandayani, Z. (2018). HARGA, KUALITAS PRODUK DAN MEREK TERHADAP KEPUTUSAN PEMBELIAN TAS KW CARTIER DI KALANGAN MAHASISWI SEBAGAI PENUNJANG PENAMPILAN KULIAH. Jurnal Ilmiah Ekonomi Global Masa Kini, 8(3), 16-22.

Azmiani Batubara, dan H. R. \&. (2016). Passenger Sales Agent. Jurnal Akuntansi, 4(1),33-46.

Batu, R. L., Suryani, N. I., Septia, N., \& Sekaryahya, P. F. (2020). Pengaruh Harga dan Inovasi Layanan Aplikasi terhadap Keputusan Penggunaan Jasa Taksi Express: Survei pada Pengunduh Aplikasi Express Taxis. Jurnal Nasional Manajemen Pemasaran \& SDM, 1(01), 1-22. https://doi.org/10.47747/jnmpsdm.v1i01.6

Buchari Alma., 2016 Manajemen Pemasaran dan Pemasaran Jasa. Bandung. Alfabeta

Dhewanto, W. (2014). Manajemen Inovasi: Peluang Sukses Menghadapi Perubahan.Yogyakarta: CV. ANDI OFFSET.

Fandy Tjiptono, 2015. Strategi Pemasaran. Ed. Empat, Andi.

Irawan, D., Marnisah, L., \& Azrai'e, K. R. (2018). ANALISIS PRODUK DAN HARGA TERHADAP KEPUTUSAN MAHASISWA UNIVERSITAS IGM MEMBELI SMARTPHONE SAMSUNG. Jurnal Ilmiah Ekonomi Global Masa Kini, 8(2), 35-41.

Kotler, Philip and Keller, Kevin Lane. 2012.Marketing Management. $14^{\text {th }}$ edition.NewJersey: Prentice.

Lukas, B.A. and Ferrel, O.C. 2000. "The Effect of Market Orientation on Product Innovation". Journal of The Academy Marketing Science. No.2 Vol.28. p.239-247.

Marnisah, L., Saputra, D., \& Azra'ie, K. R. (2016). ANALISA EFEKTIFITAS PROMOSI TERHADAP KEPUTUSAN KONSUMEN PADA MEMBELI SEMEN BARURAJA DI KELURAHAN SEKIP JAYA KECAMATAN KEMUNING PALEMBANG. Jurnal ilmiah Ekonomi Global masa kini, 7(3), 16-20.

Rangkut, Freddy. (2002). Creating Effective Marketing Plan. Teknik Membuat Marketing Plan, Berdasarkan Customoer Vallues \&Analisis Kasus. Katalog Dalam Terbitan. Gramedia Pustaka Utama, Jakarta.

Robbins, Stephen P. and Mary Coulter. 2016. Manajemen, Jilid 1 Edisi 13, Alih Bahasa: Bob Sabran Dan Devri Bardani P, Erlangga, Jakarta.

Shinta, Agustina (2011). Manajemen Pemasaran. Universitas Brawijaya Press. Malang Suprapto, Rifqi \& Azizi (2020). Ajar Manajemen Pemasaran, Cetakan Pertama, Myria Publisher. Ponorogo. 
Susanti, N., Halin, H., \& Kurniawan, M. (2018). PENGARUH BAURAN PEMASARAN (4P) TERHADAP KEPUTUSANPEMBELIAN PERUMAHAN PT. BERLIAN BERSAUDARA PROPERTINDO (Studi Kasus Perumahan Taman Arizona 1 Taman Arizona 2 dan Taman Arizona 3 di Talang Jambi Palembang). Jurnal Ilmiah Ekonomi Global Masa Kini, 8(1), 43-49. Wahid, R. M., \& Wadud, M. SOCIAL MEDIA MARKETING ON INSTAGRAM: WHEN IS THE MOST EFFECTIVE POSTING TIMING?. 